\title{
Determinants of the Consumers Green Purchase Intention in Developing Countries
}

\author{
Adnan Butt*
}

\begin{abstract}
The purpose of this study is to investigate the impact of Attitude towards Television (ATTV) on consumers' Environmental Concern (EC) and perceived consumer effectiveness (PCE) in developing countries. The model developed for the study further shows the impact of perceived consumer effectiveness (PCE) and consumers' attitude towards green purchase (ATGP) on their green purchase intention (GPI). Data from 574 respondents were collected through an online questionnaire and the hypothesized causal relationships were tested using structure equation modeling (SEM). The findings of the study revealed that ATTV has a significant impact on consumers' PCE and EC. EC was found to have a significant impact on consumers' ATGP, while the PCE and ATGP were found to have a significant impact on GPI. This study provides an insight into the importance of the use of media to enhance the consumers' environmental concerns, perceived consumer effectiveness, and consumers' attitude towards green products which ultimately has a positive impact on green purchase intention.
\end{abstract}

Keywords: Green marketing, perceived consumer effectiveness (PCE), attitude towards green purchase (ATGP), green purchase intention (GPI), structure equation modeling (SEM).

\section{Introduction}

Green products have witnessed increasing acceptance and growth in the last decade. According to the report of Global Industry Analysts Inc., 2011, by the end of 2017, the overall worldwide market of green products is expected to value over $\$ 3.5$ trillion (Sharma \& Bagoria, 2012). A recent survey has revealed that $36 \%$ of millennials are inclined to buy green products (Rogers, 2013). According to Sharma and Bagoria (2012), 25\% of the consumers in India have expressed their intention to buy green products, and around $28 \%$ may be considered health conscious.

Some of the previous studies related to green purchase intention have identified environmental concern as an important antecedent of consumers' intention (Hartmann \& Apaolaza-Ibáñez, 2012; Koenig-Lewis, Palmer, Dermody, \& Urbye, 2014; Paladino \& Ng, 2013), whereas several other studies have found the relationship to be inconsistent (Boulstridge \& Carrigan, 2000; Carrigan \& Attalla, 2001; Manaktola \& Jauhari, 2007).

The environmental concern in developing countries is at a low level and the consumers' attitude, intention, and behavior towards green alternatives are not very positive. It has also been noticed that the awareness about ecological issues in developing

*PhD scholar, Iqra University, Karachi, Pakistan. E-mail: adnan.butt@iqra.edu.pk 
countries is very low, compared to the developed countries. Similarly, one's belief to contribute anything significant to the society on individual basis is very low which reflects a low PCE level. Thus in developing countries, it is important to shape consumers' attitude and behavior towards the green products positively, and one way to do it is through influencing their environmental concern and perceived consumer effectiveness.

It is believed that the pro environmental behaviors (PEB), including recycling, conservation of energy, and buying environmentally friendly products, are the need of the time, as otherwise it would be extremely difficult for the future generations to meet their future requirements. The researcher wants to investigate that whether the factors, which showed a significant influence on consumers' behavior in developed countries, similarly influence the consumers' behavior in developing countries. The findings of the current study would enhance the understanding about the factors affecting consumers' buying intention towards green products in developing countries.

This study is the first attempt to address the issues related to green purchase intention in Pakistan and will provide an insight into the consumer behavior regarding green products. The objective of this study is to test a model regarding green purchase intention, explaining the causal relationships among the different constructs present in the model. The scope of this empirical research is to examine the causal relationship between the purchase intention with its determinants (i.e, PCE, EC, and ATGP).

The following section in the paper deals with the literature review and theoretical background of the study, which is followed by the methodology section elaborating sampling technique and data collection method. The Section four of the article is about the test results and inferences for the proposed model, and the final part of the paper presents conclusion and implications of the research,

\section{Literature Review}

\section{Green Marketing}

According to Peattie and Crane (2005), green marketing is "the process of management to recognize, anticipate, and meet the consumers' and society's needs in a sustainable way, while generating profit for the company". Murthy (2010) described green marketing as "the course of action where products or services are sold along with the management of environmental issues, either by itself or by packaging or producing in an environmental friendly method." Sustainable marketing and environmental marketing were defined by Sarkar (2012) as "the efforts of a company for distributing, promoting, and designing products that will not harm the environment by any means".

The idea about green movement was first initiated on Earth Day (i.e. April 22) in 1970 and it soon came into action during 1970's when environmental concern started to penetrate in the governmental policies. Water pollution control act, clean air act, and founding of earth day are a few of the many policies which were accommodated in public policies (Kuzmiak, 1991). No particular event could be labeled as the beginning of green movement, as it took great efforts of many people in society to start this movement (Corbett, 
2004). It is stated that 1960 s was the era of "green awakening", 1970s was classified as the period of "taking action", and 1980s was the "era of accountability", while 1990s emerged as the period of "power in the marketplace" (Makower, 1993).

It is right to say that green marketing gained more attention from late 1980s, which increased the level of green consumerism. However, the commercially manufactured green products failed to receive fruitful response in the primary phase (K. Lee, 2008), and the major reasons behind the failure of green products were high price, limited functionality, and availability (K. Lee, 2008; Bennett \& Williams, 2011). Various studies confirm that customers all over the world are inclined to buy products that are rated as eco-friendly. The consumer market for green products and services was estimated at US $\$ 230$ billion in 2009 and was predicted to grow to US $\$ 845$ billion by 2015 (Tolliver-Nigro, 2009). It is interesting to examine that whether the economic shift to be green is due to consumers' demand or because of the international pressure. Some scholars have stated that the motives of going with "Green Marketing" are competitive pressure, government pressure, social responsibilities, and market opportunities.

Most of the green marketing studies revolve around the consumer (Michaud \& Llerena, 2011), but in some green supply chain studies, other stake holders have also been included (Crittenden, Crittenden, Ferrell, Ferrell, \& Pinney, 2011; Cronin, Smith, Gleim, Ramirez, \& Martinez, 2011). The purpose of this paper is restricted to study consumer behavior only.

\section{Green Purchase Intention (GPI)}

According to Rashid (2009), green purchase intention is "the probability and one's inclination to prefer green products over traditional products in his purchase considerations". Theory of planned behavior suggests that an individual's behavioral intention is dependent on his or her attitude towards that behavior. It shows that an individual's attitude towards a particular behavior puts its impact on his or her behavioral intentions, which in turn has an effect on adoption or rejection of that particular behavior.

\section{Theoretical Framework}

In most of the previous empirical studies, researchers established their framework on the theories already developed, for instance, (Arif, Afshan, \& Sharif, 2016). Raza et al. (2015) applied the theory of reasoned action (TRA), while Muk (2007) used the theory of planned behavior (TPB) and the technology acceptance model (TAM) in their studies. Moreover, in some studies, researchers modified conjectures of TPB, TRA, and TAM successfully, as the original constructs of the theoretical models were missing (Yang \& Zhou, 2011; Gao, Moe, \& Krogstie, 2010). Similarly, Roach (2009) and Hsu, Lu, and Hsu (2007) conducted studies based on Rogers's DOI theory, by removing some of the original variables and substituting them with the new ones in the analysis.

In the light of this discussion, the hypotheses of this study have been developed on the basis of the previous empirical findings instead of using any theoretical framework. 
This methodological approach has also been used by Hooi Ting, Fong Lim, Siuly Patanmacia, Gie Low, and Chuan Ker (2011); Arif et al. (2016) and many others. Baumgartner and Steenkamp (1996) stated that rather than using a particular model to predict the consumers' intentions, it is better to work on a list of important variables affecting the consumers' intentions. This study determines the impact of an individual's beliefs (PCE) and attitudes towards green products on his or her green purchase intention.

\section{Perceived Consumer Effectiveness (PCE)}

Perceived consumer effectiveness was first explained by Kinnear, Taylor, and Ahmed (1974) as a tool to determine an individual's trust that he or she has an influence on solving environmental issues. Later researchers stated that PCE is related to the concept of perceived behavioral control (Ellen, Wiener, \& Cobb-Walgren, 1991). PCE is explained as a domain-specific belief that an individual's efforts to solve a problem would be vital. Various studies have specified that perceived consumer effectiveness is a very good predictor of plenty of consumers' pro-environmental behaviors, starting from product recycling to the use of energy-efficient alternatives (J. A. Lee \& Holden, 1999). Moreover, some studies have illustrated that green purchase intentions and behaviors, such as purchasing organic products, might be anticipated by using PCE as a predictor (Verhoef, 2005), green products (Kim \& Choi, 2005; Tan, 2011).

Berger and Corbin (1992) highlighted the contradiction between environmental attitudes and behaviors. A consumer may be worried regarding an issue in his or her individual capacity, but he or she may feel powerless to solve the problem through his or her own consumption behavior. When an individual believes that as a consumer, he or she cannot take part in solving environmental issues, the intention to consume green alternative would be diminished (Ellen et al., 1991). Kim and Choi (2005) stated that consumers with high intensity of perceived consumer effectiveness are expected to show more steadiness among attitudes, intentions, and behaviors, related to the environmental issues.

\section{Environmental Concern (EC)}

Dunlap and Robert (2002) defined Environmental concern as the belief to acknowledge the environmental problems and the inclination to get them solved by supporting environmentally friendly programs. Environmental concern leads to green marketing and the production of green products which helps in improving environmental quality and customer satisfaction (Kumar et al., 2011). Previous studies have indicated that environmental concern leads to a higher intention to use green products (Uddin \& Khan, 2016). Environmental concern motivates a customer to get involved in a buying behavior that assures individuals' and society's well-being, as the green alternatives decrease the negative consequences on the nature (Kang \& James, 2007).

Research has found that environmental concern level is much higher in women than men (Liu, Vedlitz, \& Shi, 2014) due to the socialization theory factor (Zelezny, Chua, \& Aldrich, 2000). Studies related to the age factor have indicated that younger people are more inclined towards environmental concern (Dietz, Stern, \& Guagnano, 1998) and the 
reason is very certain that values, such as education and knowledge level, differ across generations (Kanagy, Ansari, Ghosh, \& Webb, 1994).

\section{Attitude towards Green Purchase (ATGP)}

Attitude influences the human behavior which is an extensively acknowledged phenomenon in social psychology (Bredahl, 2001). The multi-attribute models, such as the theory of reasoned action (Fishbein \& Ajzen, 1977) and theory of planned behavior (Ajzen, 1985, 1991), have put forward that attitudes have an impact on people's intentions regarding a behavior, and as a result, intentions have an impact on behavior (Petty, Unnava, \& Strathman, 1991). Nevertheless, the relationship between green attitudes and behavior is still a debatable one.

Consumer behaviorists believe that one's actions can be guessed by looking at his attitude. Spruyt, Hermans, De Houwer, Vandekerckhove, and Eelen (2007) pointed out that behavior forecast directly relies on the attitude of the consumers which originates from the personal experience and knowledge they possess. Attitude is one of the most powerful factors to foresee consumers' eagerness to buy green products (Tsen, Phang, Hasan, \& Buncha, 2006).

Prior studies have shown an optimistic connection between environmental attitude and environment friendly actions (Kim \& Choi, 2005) and environmental approach with green purchase actions (Tilikidou, 2007), however, the potency of the attitude-behavior affiliation has been found to be uncertain. For instance, Diamantopoulos (1994) established a relatively weak but significant relationships among a range of environmental attitudes and the environment friendly behaviors which included buying recycled paper goods, ozone friendly aerosols, and products not tested on animals.

In today's era, customers are more conscious regarding environmental deprivation showing a concern for the society (Krajhanzl, 2010). As a result of ecological consciousness, attitude towards environmental friendly goods and services is positive. Consumers have shown favorable response to those businesses that have a concern towards the environment (Joshi \& Rahman, 2015). Due to the increase in awareness about the environmental problems, the concern towards the environment has been increased and people are willing to reduce their impact on the environment (Day \& Schoemaker, 2011).

A huge number of customers have realized the importance of environment-friendly products and shown an amplified positive attitude, as well as willingness to pay extra for green services and products (Manaktola \& Jauhari, 2007). Consumers are willing to pay an additional amount in support of eco-friendly products, if the quality of the products is maintained (D'Souza, Taghian, \& Khosla, 2007).

According to Krause (1993), consumers' concern is getting high regarding their impact on the environment and about their buying habits. Some consumers have shown their seriousness by purchasing the green alternatives on regular basis (Martin \& Simintiras, 1995). Most of the times, consumers do not make product purchase decisions based only on environmental attitude, however, it is emerging as an essential factor in consumer buying behavior (Irland, 1993). 


\section{Attitude towards Television / Media (ATTV)}

Social Learning Theory states that when humans are encouraged to learn a particular behavior through observing a model, they would learn more easily (Haroon, ul Haq, et al., 2015). According to Baran and Davis (2000), modeling or imitation is "the primary, mechanical reproduction of behavior". When a customer perceives a model being honored for a certain behavior, the viewer will be more likely to accomplish the behavior. Media can be used to present the model behavior to the public which is expected to be imitated by the masses.

According to Brown (2002), media transform the thought process of the individuals. The viewers mostly start relying on the material shown to them on TV and form their views accordingly. Media set the priorities of the viewers by emphasizing a particular topic and making it more attractive for the viewers (Holbert, Kwak, \& Shah, 2003). Different studies have found a positive relationship between environmental concerns and exposure to the pro-environment media content (Good, 2006). Brothers, Fortner, and Mayer (1991) observed a strong positive relationship between the coverage of environmental issues in television news and individual-level knowledge of ecological problems. A strong link was established between news coverage of environmental matters and people's knowledge, concern, and attitude towards environmental issues.

It can be rightly said that the media have played a vital role in the success of environment related campaigns. Media disseminate the thought of environmental concerns among the masses. The massive media attention to different environment related events has transformed the small problems into the main stream public issues (Qader \& Zainuddin, 2011). This focus of media has changed the people's concerns towards the environment and people have started to think about climate change, environmental degradation, pro-environment behaviors, and use of green products. According to Awad (2011), this shift in consumers' attitude towards environment and green products has created a strong link among environment, consumer behavior and marketing.

Due to the huge developments in communication technologies, media can be used to create awareness among the audience about environmental issues and enhance the consumers' belief that his or her individual efforts are not useless, through especially targeting the suburban localities of the country. Media can be used in many ways to spread the environment related messages and one of the tools can be green advertising. Like traditional advertising, green advertising not only informs, reminds, and persuades the consumers, but also creates awareness and positive attitudes toward eco-friendly brands and firms (D'souza \& Taghian, 2005). Green advertising can be used to enhance the consumer information level about the eco-friendly aspects of the green products and services (Pranee, 2010). Green advertising can also be used to reinforce the idea that individual participation in the environmental protection campaign is the most vital ingredient. On the basis of the foregoing discussion, the following hypotheses are proposed for the study:

$H a_{1}$ : Attitude towards television has a significant impact on perceived consumer effectiveness.

$\mathrm{Ha}_{2}$ : Attitude towards television has a significant impact on environmental concern. 
$\mathrm{Ha}_{3}$ : Perceived Consumer Effectiveness has a significant impact on Green Purchase Intention.

$\mathrm{Ha}_{4}$ : Environmental concern has a significant impact on attitude towards green purchase.

$H_{5}$ : Attitude towards green purchase has a significant impact on green purchase intention.

Figure 1

Conceptual Framework

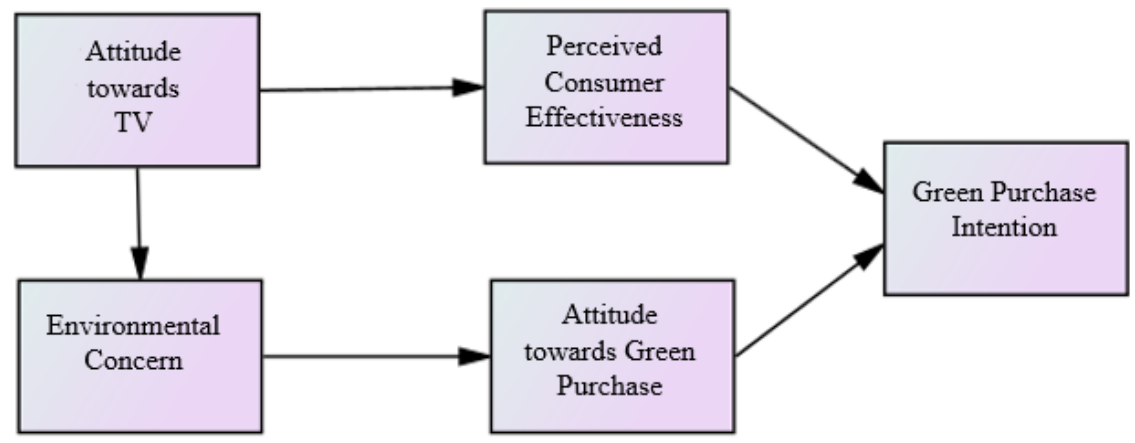

\section{Methodology}

\section{Research Method}

This study is quantitative in nature following a deductive approach with an objective to examine the factors which influence the consumers' attitude and purchase intention towards green products. Therefore, the unit of analysis to fulfill the research objective is consumer. The sample was selected on the basis of respondents' prior exposure to the green products and their capability of making their purchase decisions independently. With experts' consultation, it was decided that 18 years or older consumers are capable to make independent purchase decisions. The sample size was 600 and most of the data were collected from the university students as they meet both the above mentioned criteria. A questionnaire survey method was used to collect the data through google forms. From the data of 600 respondents, 26 were classified as outliers by using multivariate outlier technique because of having unusual combination of the values, so they were excluded from the sample.

Respondents were approached in class rooms as well as through SMS, whatsApp groups, and social interactive websites and asked to fill the online questionnaire. Only participants who are the residents of Karachi were asked to complete the task. Demographic questions were asked in the first part of the instrument regarding participants' age, gender, education and marital status. The second part of the questionnaire comprised items related to the variables in the research model. 


\section{Measures}

The instrument was prepared by using the measures drawn from the related literature. These measures have been widely used before and are considered valid and reliable. Perceived consumer effectiveness was measured by using four items from the scale of Roberts (1996). To measure environmental concern, five items from Kilbourne and Pickett (2008)'s scale were used. All of the items were measured on a five point likert scale (1 strongly disagree to 5 strongly agree). Three items from Ling-Yee (1997)'s scale were used to measure green purchase intention on a seven point scale ( 1 very unlikely to 7 very likely).

Attitude towards green purchases was measured by three items from the scale developed by Taylor and Todd (1995). In the first question, a seven-point scale was used that ranged from 1 (dislike) to 7 (like). The second item was measured on a seven-point scale that ranged from 1 (bad) to 7 (good). The third item was measured on a seven-point scale that ranged from 1 (unfavorable) to 7 (favorable).

Overall, the respondents' attitude towards television in general was measured on three adjectives. All the questions were measured on a seven-point scale. The first question was measured on a scale from 1 (unfavorable) to 7 (favorable), the second question was measured on a scale of 1 (bad) to 7 (good), while the third question was measured on a scale from 1 (negative) to 7 (positive).

\section{Demographics}

The 574 respondents had the following demographic characteristics: 379 (66\%) were male and 195 (34\%) were female; 440 (76.7\%) were in bachelor's program, $111(19.3 \%)$ were in master's program, $9(1.6 \%)$ were enrolled in MPhil or equivalent degree programs, 2 $(0.3 \%)$ had a doctoral degree, and $12(2.1 \%)$ respondents were in the other category; 457 $(79.6 \%)$ were aged 18 to 25 years, $103(17.9 \%)$ were aged 25 to 35 years, $13(2.3 \%)$ were aged 35 to 50 years, and one respondent $(0.001 \%)$ was aged 50 years or more; $528(92 \%)$ were unmarried or single and $46(8 \%)$ were married. Table 1 shows the demographic characteristics of the respondents.

\section{Analysis and Results}

\section{Exploratory Factor Analyses (EFA)}

In this study, all the constructs used in the questionnaire are adopted from the existing literature and from established and validated measurement scales. EFA was run on the SPSS 21 and the values of KMO (0.86) and Bartlett's Sphericity test $(p<0.001)$ confirmed the data suitability for the factor analysis. The results showed the solution with 5 factors having eigenvalues $>1$ and accounting for $67.3 \%$ of the total variance. All the items having factor loading values greater than 0.40 were kept in the analysis (Stevens, 1992). The items and factor loadings are given in the table II. 
Table 1

Demographics

\begin{tabular}{lccc}
\hline \multirow{3}{*}{ Gender } & & No & $\%$ \\
\hline \multirow{4}{*}{ Age } & Male & 379 & 66 \\
& Female & 195 & 34 \\
\hline \multirow{4}{*}{ Education } & 18 to 25 & 457 & 79.6 \\
& 25 to 35 & 103 & 17.9 \\
& 35 to 50 & 13 & 2.3 \\
& 50 or above & 1 & 0.001 \\
\hline \multirow{2}{*}{ Marital Status } & Bachelor & 440 & 76.7 \\
& Master & 111 & 19.3 \\
\multirow{2}{*}{ N $=574$} & Mphil & 9 & 1.6 \\
& Doctoral & 2 & 0.3 \\
& Others & 12 & 2.1 \\
\hline
\end{tabular}

\section{Confirmatory Factor Analysis (CFA)}

Initially the CFA model was developed and after the finalization of CFA model, the data were used for testing the structural model. Model fitness of CFA model was checked by using different indices. The researcher tried to have all the factor loadings above the recommended minimum value of .60 (J. F. J. Hair, Black, Babin, Anderson, \& Tatham, 2006), but some items were found to have factor loadings of less than 0.6. All the items having the value of less than 0.6 were deleted one by one from the model to improve the results. The item having the lowest factor loading was deleted first. The deleted items are PCE2, PCE3, EC1 and EC2. After deleting all the items having low factor loadings from the constructs respectively, the model fit improved considerably. The values are $\chi^{2}$ $=113.37 ; \mathrm{df}=55 ; \mathrm{p}<.000 ; \mathrm{CFI}=.981 ; \mathrm{TLI}=0.974 ; \mathrm{GFI}=.971 ; \mathrm{RMSEA}=.043$. According to $\mathrm{Hu}$ and Bentler (1999) criteria, all the values show that model fit is good and well above the acceptable values. The table III shows the factor loadings of all the items in the model.

To test the reliability of the constructs, the composite reliability (CR) and average variance extract (AVE) values were calculated. Composite reliability shows the reliability of a summated scale and average variance extracted tells the variance in the indicators explained by the common factor. AVE value greater than 0.5 indicates that the validity of the construct and the individual variables is high (Dillon \& Goldstein, 1984).

In this study, the AVE value of PCE and EC is bit lower than the bench mark of 0.5, but according to Fornell and Larcker (1981), if AVE is less than 0.5, but composite reliability is higher than 0.6 , the convergent validity of the construct is still adequate. The CR value of all the constructs is greater than 0.6, but PCE and EC have CR values of less than 0.7, as recommended by (J. F. Hair et al., 1998). 
Table 2

Factor Loadings

Perceived Consumer Effectiveness (Cronbach's $\alpha=0.613$ )

It is worth it for the individual consumer to make efforts to preserve and improve the environment.

When I buy products, I tend to try to consider how my use of them will affect the environment.

Since each individual can have any effect upon environmental problems, what I do can make

meaningful difference.

By purchasing products made in an environmentally friendly way, each consumer's

behavior can have a positive effect on the environment and society.

Environmental Concern (Cronbach's $\alpha=0.671$ )

I am very concerned about the environment.

Major political change is necessary to protect the natural environment 0.588

Major social changes are necessary to protect the natural environment. 0.767

Anti-pollution laws should be enforced more strongly.

I would be willing to reduce my consumption to help protect the environment.

Attitude toward Media (Cronbach's $\alpha$ 0.885)

Overall what is your attitude towards television in general (unfavorable / favorable) 0.850

Overall what is your attitude towards television in general (bad / good)

'Overall what is your attitude towards television in general (negative / positive)

Attitude toward green purchase (Cronbach's $\alpha=0.812$ )

I — the idea of purchasing green (like / dislike)

$\begin{array}{ll}\text { Purchasing green is a— idea (bad / good) } & 0.859\end{array}$

I have a/an
(favorable / unfavorable)

Green Purchase Intention (Cronbach's $\alpha=0.869$ )

Over the next one month, I will consider buying products because they are less polluting 0.823

Over the next one month, I will consider switching to other brands for ecological reasons 0.865

$\begin{array}{ll}\text { Over the next one month, I plan to switch to a green version of a product } & 0.840\end{array}$

Table 3

Discriminant Validity

\begin{tabular}{lccccc}
\hline Measures & ATTV & PCE & EC & ATGP & GPI \\
\hline ATTV & $\mathbf{0 . 8 4 7}$ & & & & \\
PCE & 0.094 & $\mathbf{0 . 6 5 4}$ & & & \\
EC & 0.142 & 0.651 & $\mathbf{0 . 6 8 1}$ & & \\
ATGP & 0.238 & 0.378 & 0.366 & $\mathbf{0 . 7 9 8}$ & \\
GPI & 0.24 & 0.399 & 0.277 & 0.495 & $\mathbf{0 . 9 2 7}$ \\
\hline
\end{tabular}

To check the discriminant validity, the method of Fornell and Larcker (1981) was adopted. It suggests that the AVE of the latent variable should be compared with the correlation among the constructs. According to J. F. J. Hair et al. (2006), the square root of AVE should be greater than the correlation among the constructs. The values shown in table IV explain that there is no significant issue of discriminant validity in the data.

\section{SEM Estimations and Test of Hypothesis}

After finalizing the CFA model, the structural model was run to test the proposed hypotheses on AMOS 21 and the following results were obtained: $\chi^{2}=231.18 ; \mathrm{df}=60 ; \mathrm{p}=$ $.000 ; \mathrm{CFI}=.924 ; \mathrm{TLI}=0.913 ; \mathrm{GFI}=.932 ; \mathrm{RMSEA}=.071$. The results show that the first 


\begin{tabular}{lccc}
$\begin{array}{l}\text { Table } 4 \\
\text { Reliability and Confirmatory Factor Loadings }\end{array}$ & & \\
\hline Items & $\begin{array}{c}\text { Standardized } \\
\text { Factor loading }\end{array}$ & $\begin{array}{c}\text { Composite } \\
\text { Reliability }\end{array}$ & $\begin{array}{c}\text { Average Variance } \\
\text { Extracted }\end{array}$ \\
\hline $\begin{array}{l}\text { Perceived Consumer Effectiveness (PCE) } \\
\text { PCE1 }\end{array}$ & 0.691 & 0.601 & 0.420 \\
PCE4 & 0.604 & & \\
\hline Environmental Concern (EC) & & & 0.464 \\
EC3 & 0.688 & 0.634 & \\
EC4 & 0.675 & & \\
\hline Attitude Towards Television (ATTV) & & & \\
ATTV1 & 0.755 & & \\
ATTV2 & 0.930 & 0.884 & \\
ATTV3 & 0.850 & & 0.638 \\
\hline Attitude Towards Green Purchase (ATGP) & & & \\
ATGP1 & 0.809 & & \\
ATGP2 & 0.840 & 0.841 & \\
ATGP3 & 0.744 & & \\
\hline Green Purchase Intention (GPI) & & & \\
GPI & 0.824 & & \\
GPI2 & 0.820 & 0.869 & \\
GPI3 & 0.815 & & \\
\hline
\end{tabular}

hypothesis, Attitude towards TV has an impact on Perceived Consumer Effectiveness, has been accepted $(\beta=.084 ; \mathrm{p}<.05)$. This shows that consumers who have a positive attitude towards TV/media would have a higher value of PCE. The results suggest that media can be used to influence the consumer PCE level and through proper media campaigns, consumers' beliefs regarding their individual contribution to the resolution of environmental issues can be altered or modified. This positive impact of media campaigns on consumers' PCE level is expected to create favorable intentions among consumers to behave in an environmental friendly manner.

The second hypothesis, Attitude towards TV has an impact on Environmental Concern, has also been accepted $(\beta=.093 ; \mathrm{p}<.05)$. The results show that there is a positive correlation between ATTV and EC, implying that people having a positive attitude towards TV / media would have a higher concern for the environmental issues. Here two inferences can be made: TV has enhanced the general public concern towards the environmental issues, and media can be used to enhance the environmental concern of the public.

The third hypothesis, Environmental Concern has an impact on Attitude towards Green Purchase, has also been accepted $(\beta=.701 ; \mathrm{p}<.001)$. It shows that those people who have a high concern towards the environmental issues would show a more positive attitude towards green purchases. These results imply that in order to make people's attitude positive towards green alternatives, their environmental concerns should be raised. Consumers should be convinced that environmental issues are as important to them as their personal issues. If the government and corporations are successful in increasing people's environmental concerns, the overall attitude of the society towards green purchase will become favorable.

The fourth hypothesis, Perceived consumer effectiveness has an impact on green purchase intention, has also been accepted $(\beta=.416 ; \mathrm{p}<.001)$. These results are similar to the 
findings of Kim and Choi (2005) and Joonas (2008) and reveal that people with a higher PCE level would have a higher intention to buy green products. The acceptance of this hypothesis endorses the fact that if people's beliefs regarding effectiveness of individual efforts are strengthened, their intention to use green products would be augmented.

\begin{tabular}{|c|c|c|c|c|c|}
\hline Hypothesis & Path & Coefficients & t-value & Sig value & Result \\
\hline 1 & ATTV has an impact on PCE & 0.093 & 3.208 & $* * .001$ & Accepted \\
\hline 2 & ATTV has an impact on EC & 0.084 & 2.264 & $* * .024$ & Accepted \\
\hline 3 & PCE has an impact on GPI & 0.416 & 3.350 & $* * * .000$ & Accepted \\
\hline 4 & EC has an impact on ATGP & 0.701 & 6.130 & $* * * .000$ & Accepted \\
\hline 5 & ATGP has an impact on GPI & 0.464 & 9.290 & $* * * .000$ & Accepted \\
\hline
\end{tabular}

Finally, the fifth hypothesis, Attitude towards Green Purchase has an impact on Green Purchase Intention, has also been accepted $(\beta=.464 ; \mathrm{p}<.001)$, validating the finding of Tsen et al. (2006) and suggesting that the attitude is the foremost factor to foresee the willingness of consumers to buy green products. It shows that people having a positive attitude towards green products would have a higher intention to buy green products. It suggests that if the people's intention to buy green alternative is to be triggered, their attitude towards green products needs to be made positive.

\section{Discussion and Conclusion}

The major purpose of this study was to propose a conceptual model regarding the relationship of perceived consumer effectiveness, consumers' attitude towards green purchase, and their green purchase intentions, with the consideration of media impact. The model proposed in this study explains different propositions regarding green purchase intention, including propositions about the effect of media on consumers' PCE, CE, and their attitude towards green purchase.

The results have revealed that media has an impact on consumers' PCE and EC level. The people possessing a positive attitude towards media have been found to have higher PCE and EC levels. This implies that media can be used to make a consumer realize that his or her individual contribution is very vital for the success of these efforts. Consumers should be communicated that their individual efforts will not be wasted. The proper media campaigns should be planned and run to emphasize that overall betterment in the society would be the result of every individual's contribution. The individual's strong belief to influence the overall situation would lead to a higher intention to buy green products, so it can be inferred that a higher PCE level leads to a higher green purchase intention.

Media can also be used to create awareness among the public about the environmental issues and their responsibility towards the protection of the environment. It should be emphasized that the environmental issues have a direct impact on every individual's life, so everyone must play a role in preserving and protecting the environment. Media cam- 
paigns can be run to stress the fact that anything which is harmful for the environment, directly harms every individual personally.

\section{Figure 2}

Measurement of Model

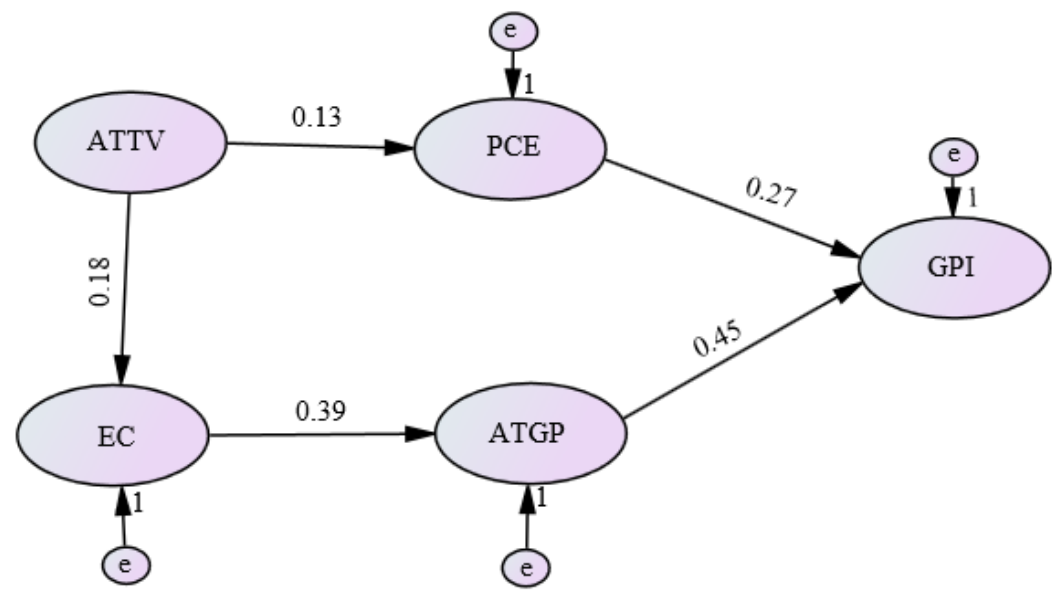

When a consumer has a firm belief that environmental issues are important for him or her and these issues need to be urgently dealt with, this would have a significant and positive impact on consumers' attitude towards green purchase. The results suggests that when EC level of the consumers is high, the consumers would have a positive attitude towards green products. So it can be inferred here that people having a high EC level would show a better response towards the green alternatives. As a result, their attitude towards green products' purchase would be appreciative and positive rather than critical and negative.

The results also suggest that this shift in attitude towards green purchase will influence the consumers' intentions to buy green products. The overall conclusion from the findings of this study is that people's PCE and EC levels can be influenced very effectively through media by running convincing marketing campaigns. Once the consumers are convinced that environmental issues are related to them and their individual efforts can make a difference, their attitude towards green purchase would be positive. It is expected from the findings that this positive shift in consumers' attitude and PCE levels would augment their behavioral intentions to buy green products.

\section{Research Implications}

The findings of this study have theoretical and managerial contributions. On the theoretical end, this research helps us understand the role of media in influencing the consumers' perceptions, attitudes and behavioral intentions regarding green marketing and products. It is suggested that through targeting consumers' PCE and EC primarily, their 
attitude and purchase intentions for green products can be influenced positively in the developing countries.

Previous research has found consumers' PCE and EC levels in developing countries to be very low, as the consumers there do not believe in the effectiveness of their individual efforts, and consequently they do not try to make things better in their environment. It is logical that if consumers believe that environmental issues are not related to them personally, they will make little effort to take care of the environment. The results of this study suggest that media should be used effectively to raise the PCE and EC levels of consumers in the developing countries.

The separate media campaigns can be designed for the consumers with higher PCE and EC levels focusing on appreciating their efforts in order to encourage and reinforce their actions and behaviors. On the other hand, a different type of media campaigns concentrating on the importance of an individual's efforts can be run to target the people with lower PCE and EC levels, in order to enhance their awareness about environmental issues and make them realize the importance of their efforts.

It is expected that these media campaigns would have a significant effect on consumers' attitude and use of green products. These media campaigns would highlight the non-monetary cost of the non-green products which is usually not considered by majority of the consumers. It is recommended to both the corporate sector and the government that environmental issues should be communicated to the consumers and the general public properly by using the appropriate medium. Because without creating a sense of responsibility in the masses, the dream of sustainable growth cannot be achieved.

A set of variables were used to estimate the attitude towards green purchase and green purchase intention in this study, but some other variables such as Environmental locus of control (ELOC) may also be used as independent variables in the model. The data were collected through google form and majority of the questionnaires were filled in the absence of the researcher, so the probability of consumers' response biasness cannot be ignored. Majority of the data were collected from the urban population, so it is expected that if the respondents with different demographic composition were used in the study, the results might have been different from the findings of the current study.

The main purpose of this study was to investigate the consumers' attitude towards green purchase and green purchase intention. It is proposed that for future studies, researchers may try to examine the relationship between green purchase intention and actual green purchase behavior. The researchers may also examine the relationship between behavioral intentions and other pro-environmental behaviors (PEBs). It is also suggested that researchers investigate the impact of respondents' demographic characteristics, such as gender, age and education, on green purchase intention and green purchase behavior. 


\section{References}

Ajzen, I. (1985). From intentions to actions: A theory of planned behavior. Springer Berlin Heidelberg.

Ajzen, I. (1991). The theory of planned behavior. Organizational Behavior and Human Decision Processes, 50(2), 179-211.

Arif, I., Afshan, S., \& Sharif, A. (2016). Resistance to mobile banking adoption in a developing country: Evidence from modified TAM model. Journal of Finance $\mathcal{E}$ Economics Research, 1(1), 25-42.

Awad, T. A. (2011). Environmental segmentation alternatives: Buyers' profiles and implications. Journal of Islamic Marketing, 2(1), 55-73.

Baran, S. J., \& Davis, D. K. (2000). Theories of media, culture, and society. Mass communication theory: Foundations, ferment, and future. Belmont, CA: Wadsworth Publishing Company.

Baumgartner, H., \& Steenkamp, J.-B. E. (1996). Exploratory consumer buying behavior: Conceptualization and measurement. International Journal of Research in Marketing, 13(2), 121-137.

Bennett, G., \& Williams, F. (2011). Mainstream green: Moving sustainability from niche to normal. Psychological Bulletin, 107(2), 238.

Berger, I. E., \& Corbin, R. M. (1992). Perceived consumer effectiveness and faith in others as moderators of environmentally responsible behaviors. Journal of Public Policy $\mathcal{E}$ Marketing, 11(2), 79-100.

Boulstridge, E., \& Carrigan, M. (2000). Do consumers really care about corporate responsibility? Highlighting the attitude-behaviour gap. Journal of Communication Management, 4(4), 355-368.

Bredahl, L. (2001). Determinants of consumer attitudes and purchase intentions with regard to genetically modified food-results of a cross-national survey. Journal of Consumer Policy, 24(1), 23-61.

Brothers, C. C., Fortner, R. W., \& Mayer, V. J. (1991). The impact of television news on public environmental knowledge. The Journal of Environmental Education, 22(4), 2229.

Brown, J. D. (2002). Mass media influences on sexuality. Journal of Sex Research, 39(1), 42-45.

Carrigan, M., \& Attalla, A. (2001). The myth of the ethical consumer-do ethics matter in purchase behaviour? Journal of Consumer Marketing, 18(7), 560-578.

Corbett, S. (2004). Green states and social movement's environmentalism in the United States, United Kingdom, Germany and Norway. Australian and New Zealand Journal of Public Health, 28, 96-104.

Crittenden, V. L., Crittenden, W. F., Ferrell, L. K., Ferrell, O., \& Pinney, C. C. (2011). Market-oriented sustainability: a conceptual framework and propositions. Journal of the Academy of Marketing Science, 39(1), 71-85.

Cronin, J. J., Smith, J. S., Gleim, M. R., Ramirez, E., \& Martinez, J. D. (2011). Green marketing strategies: an examination of stakeholders and the opportunities they present. Journal of the Academy of Marketing Science, 39(1), 158-174. 
Day, G. S., \& Schoemaker, P. J. (2011). Innovating in uncertain markets: 10 lessons for green technologies. MIT Sloan Management Review, 52(4), 37-45.

Diamantopoulos, A. (1994). Modelling with lisrel: A guide for the uninitiated. Journal of Marketing Management, 10(1-3), 105-136.

Dietz, T., Stern, P. C., \& Guagnano, G. A. (1998). Social structural and social psychological bases of environmental concern. Environment and Behavior, 30(4), 450-471.

Dillon, W. R., \& Goldstein, M. (1984). Multivariate analysis: Methods and applications. New York: John Wiley \& Sons.

D'souza, C., \& Taghian, M. (2005). Green advertising effects on attitude and choice of advertising themes. Asia Pacific Journal of Marketing and Logistics, 17(3), 51-66.

D'Souza, C., Taghian, M., \& Khosla, R. (2007). Examination of environmental beliefs and its impact on the influence of price, quality and demographic characteristics with respect to green purchase intention. Journal of Targeting, Measurement and Analysis for Marketing, 15(2), 69-78.

Dunlap, R. E., \& Robert, E. J. (2002). Environmental concern: Conceptual and measurement issues. In handbook of environmental sociology. Westport, CT: Greenwood Press.

Ellen, P. S., Wiener, J. L., \& Cobb-Walgren, C. (1991). The role of perceived consumer effectiveness in motivating environmentally conscious behaviors. Journal of Public Policy \& Marketing, 10(2), 102-117.

Fishbein, M., \& Ajzen, I. (1977). Belief, attitude, intention, and behavior: An introduction to theory and research. Reading, MA: Addison-Wesley.

Fornell, C., \& Larcker, D. F. (1981). Evaluating structural equation models with unobservable variables and measurement error. Journal of Marketing Research, 18(1), 39-50.

Gao, S., Moe, S. P., \& Krogstie, J. (2010). An empirical test of the mobile services acceptance model. In Mobile Business and 2010 Ninth Global Mobility Roundtable (ICMB-GMR), 2010 Ninth International Conference (pp. 168-175).

Good, J. (2006). Internet use and environmental attitudes: A social capital approach. The Environmental Communication Yearbook, 3, 211-233.

Hair, J. F., Black, W. C., Babin, B. J., Anderson, R. E., Tatham, R. L., et al. (1998). Multivariate data analysis. Upper Saddle River, NJ: Prentice Hall.

Hair, J. F. J., Black, W. C., Babin, B. J., Anderson, R. E., \& Tatham, R. L. (2006). Multivariate data analysis. New Delhi: Pearson Education.

Haroon, M. Z., ul Haq, M. A., et al. (2015). Impact of role model on behavioral and purchase intentions among youngsters: Empirical evidence from Karachi, Pakistan. Journal of Management Sciences, 2(2), 242-254.

Hartmann, P., \& Apaolaza-Ibáñez, V. (2012). Consumer attitude and purchase intention toward green energy brands: The roles of psychological benefits and environmental concern. Journal of Business Research, 65(9), 1254-1263.

Holbert, R. L., Kwak, N., \& Shah, D. V. (2003). Environmental concern, patterns of television viewing, and pro-environmental behaviors: Integrating models of media consumption and effects. Journal of Broadcasting E Electronic Media, 47(2), 177-196.

Hooi Ting, D., Fong Lim, S., Siuly Patanmacia, T., Gie Low, C., \& Chuan Ker, G. (2011). Dependency on smartphone and the impact on purchase behaviour. Young Consumers, 12(3), 193-203. 
Hsu, C.-L., Lu, H.-P., \& Hsu, H.-H. (2007). Adoption of the mobile internet: An empirical study of multimedia message service (MMS). Omega, 35(6), 715-726.

Hu, L.-t., \& Bentler, P. M. (1999). Cutoff criteria for fit indexes in covariance structure analysis: Conventional criteria versus new alternatives. Structural Equation Modeling: A Multidisciplinary Journal, 6(1), 1-55.

Irland, L. C. (1993). Wood producers face green marketing era: Environmentally sound products. Wood Technology, 120(2), 34-36.

Joonas, K. (2008). Environmentally friendly products: factors affecting search for information. AIMS International Journal of Management, 2(3), 165-176.

Joshi, Y., \& Rahman, Z. (2015). Factors affecting green purchase behaviour and future research directions. International Strategic Management Review, 3(1), 128-143.

Kanagy, N. L., Ansari, M. N., Ghosh, S., \& Webb, R. C. (1994). Recycling and buffering of intracellular calcium in vascular smooth muscle from genetically hypertensive rats. Journal of Hypertension, 12(12), 1365-1372.

Kang, G.-D., \& James, J. (2007). Revisiting the concept of a societal orientation: Conceptualization and delineation. Journal of Business Ethics, 73(3), 301-318.

Kilbourne, W., \& Pickett, G. (2008). How materialism affects environmental beliefs, concern, and environmentally responsible behavior. Journal of Business Research, 61(9), 885-893.

Kim, Y., \& Choi, S. M. (2005). Antecedents of green purchase behavior: An examination of collectivism, environmental concern, and pce. Advances in Consumer Research, 32(1), 592-599.

Kinnear, T. C., Taylor, J. R., \& Ahmed, S. A. (1974). Ecologically concerned consumers: who are they? The Journal of Marketing, 38(2), 20-24.

Koenig-Lewis, N., Palmer, A., Dermody, J., \& Urbye, A. (2014). Consumers' evaluations of ecological packaging-rational and emotional approaches. Journal of Environmental Psychology, 37, 94-105.

Krajhanzl, J. (2010). Environmental and proenvironmental behavior. School and Health, $21,251-274$.

Krause, D. (1993). Environmental consciousness: An empirical study. Environment and Behavior, 25(1), 126-142.

Kumar, P. D., et al. (2011). Green marketing: A start to environmental safety. Advances in Management.

Kuzmiak, D. (1991). The American environmental movement. Geographical Journal, 157(3), 265-278.

Lee, J. A., \& Holden, S. J. (1999). Understanding the determinants of environmentally conscious behavior. Psychology and Marketing, 16(5), 373-392.

Lee, K. (2008). Opportunities for green marketing: young consumers. Marketing Intelligence \& Planning, 26(6), 573-586.

Ling-Yee, L. (1997). Effect of collectivist orientation and ecological attitude on actual environmental commitment: The moderating role of consumer demographics and product involvement. Journal of International Consumer Marketing, 9(4), 31-53.

Liu, X., Vedlitz, A., \& Shi, L. (2014). Examining the determinants of public environmental concern: Evidence from national public surveys. Environmental Science E Policy, 39, 
77-94.

Makower, J. (1993). The e-factor: The bottom line approach to environmentally friendly business. Tilden Press, New York, NY.

Manaktola, K., \& Jauhari, V. (2007). Exploring consumer attitude and behaviour towards green practices in the lodging industry in India. International Journal of Contemporary Hospitality Management, 19(5), 364-377.

Martin, B., \& Simintiras, A. C. (1995). The impact of green product lines on the environment: Does what they know affect how they feel? Marketing Intelligence E Planning, 13(4), 16-23.

Michaud, C., \& Llerena, D. (2011). Green consumer behaviour: An experimental analysis of willingness to pay for remanufactured products. Business Strategy and the Environment, 20(6), 408-420.

Muk, A. (2007). Consumers' intentions to opt in to SMS advertising: A cross-national study of young Americans and Koreans. International Journal of Advertising, 26(2), 177-198.

Murthy, P. (2010). Strategic green marketing for survival. Electronic copy available at SSRN. doi: $10.2139 /$ ssrn

Paladino, A., \& Ng, S. (2013). An examination of the influences on 'green' mobile phone purchases among young business students: An empirical analysis. Environmental Education Research, 19(1), 118-145.

Peattie, K., \& Crane, A. (2005). Green marketing: legend, myth, farce or prophesy? Qualitative Market Research: An International Journal, 8(4), 357-370.

Petty, R. E., Unnava, R. H., \& Strathman, A. J. (1991). Theories of attitude change. Englewood Cliffs, NJ: Prentice-Hall.

Pranee, C. (2010). Marketing ethical implication \& social responsibility. International Journal of Organizational Innovation (Online), 2(3), 6-21.

Qader, I. K. A., \& Zainuddin, Y. B. (2011). The impact of media exposure on intention to purchase green electronic products amongst lecturers. International Journal of Business and Management, 6(3), 240-248.

Rashid, N. R. N. A. (2009). Awareness of eco-label in Malaysia's green marketing initiative. International Journal of Business and Management, 4(8), 132.

Roach, G. (2009). Consumer perceptions of mobile phone marketing: A direct marketing innovation. Direct marketing: An International Journal, 3(2), 124-138.

Roberts, J. A. (1996). Green consumers in the 1990s: Profile and implications for advertising. Journal of Business Research, 36(3), 217-231.

Rogers, G. (2013). The rise of generation $Y$ in the sustainable marketplace. The Guardian, February 4. Retrieved from http://www.guardian.co.uk/sustainable -business/blog/risegeneration-y-sustainable-marketplace

Sarkar, A. (2012). Green branding and eco-innovations for evolving a sustainable green marketing strategy. Asia-Pacific Journal of Management Research and Innovation, 8(1), 39-58.

Sharma, S. C., \& Bagoria, H. (2012). Green marketing: A gimmick or the real deal. International Journal of Research in Finance \& Marketing, 2(2), 406-414. 
Spruyt, A., Hermans, D., De Houwer, J., Vandekerckhove, J., \& Eelen, P. (2007). On the predictive validity of indirect attitude measures: Prediction of consumer choice behavior on the basis of affective priming in the picture-picture naming task. Journal of Experimental Social Psychology, 43(4), 599-610.

Stevens, J. P. (1992). Applied multivariate statistics for the social sciences. Hillsdale, NJ: Erlbaum.

Tan, B.-C. (2011). The roles of knowledge, threat, and PCE on green purchase behaviour. International Journal of Business and Management, 6(12), 14-27.

Taylor, S., \& Todd, P. A. (1995). Understanding information technology usage: A test of competing models. Information Systems Research, 6(2), 144-176.

Tilikidou, I. (2007). The effects of knowledge and attitudes upon Greeks' proenvironmental purchasing behaviour. Corporate Social Responsibility and Environmental Management, 14(3), 121-134.

Tolliver-Nigro, H. (2009). Green market to grow 267 percent by 2015. Matter Network, 29. Retrieved from www.matternetwork.com/2009/6/green-market-grow -267-percent. cfm

Tsen, C.-H., Phang, G., Hasan, H., \& Buncha, M. R. (2006). Going green: A study of consumers' willingness to pay for green products in Kota Kinabalu. International Journal of Business and Society, 7(2), 40-54.

Uddin, S. F., \& Khan, M. N. (2016). Exploring green purchasing behaviour of young urban consumers: Empirical evidences from India. South Asian Journal of Global Business Research, 5(1), 85-103.

Verhoef, P. C. (2005). Explaining purchases of organic meat by dutch consumers. European Review of Agricultural Economics, 32(2), 245-267.

Yang, H. C., \& Zhou, L. (2011). Extending TPB and TAM to mobile viral marketing: An exploratory study on American young consumers' mobile viral marketing attitude, intent and behavior. Journal of Targeting, Measurement and Analysis for Marketing, 19(2), 85-98.

Zelezny, L. C., Chua, P.-P., \& Aldrich, C. (2000). New ways of thinking about environmentalism: Elaborating on gender differences in environmentalism. Journal of Social Issues, 56(3), 443-457. 